\title{
АДАПТИВНЫЙ ПОТЕНЦИАЛ ЛИЧНОСТИ В УСЛОВИЯХ ПРЕДЕЛЬНОГО УПЛОТНЕНИЯ МЕДИЙНЫХ КОММУНИКАЦИЙ
}

\author{
А. К. ПОЛЯНИНА \\ Национальный исследовательский Нижегородский государственный университет имени \\ Н. И. Лобачевского; филиал Самарского государственного университета путей сообщения, \\ г. Нижний Новгород, Россия
}

Мир стоит перед вызовом трансформации всех известных аспектов социальной жизни, в основании которых лежит коммуникация. Факторы личностной идентичности, в том числе религиозной, на сегодняшний день претерпевают радикальные изменения, связанные, прежде всего, с экспансией логикой медиасети всего жизненного пространства ${ }^{1}$. Эта логика не имеет ничего общего со структурностью, порядком и устройством, она основывается на семиотической гомогенности мира и общества. Трансформация информационно-медийного пространства, начавшаяся более тридцати лет назад, обуславливает динамику адаптационных процессов.

Необходимость формирования, развития и сохранения идентичности, культурной, религиозной, национальной, и даже половой, ставит современного человека перед необходимостью борьбы с закона постмодернистского типа цивилизации, а часто, болезненного противопоставления ему. Эпоха коммуникационного изобилия ${ }^{2}$ выстаивает соответствующую форму сознания людей, сознания, свободного от «травмирующей» нормы, от границ и требований, лишённого автономии, и не способного, как это ни парадоксально, на произвол. Произвол как начало автономии, имманентное природе волеизъявления опосредуется волей ${ }^{3}$, которая перестаёт быть необходимостью в мире «дозволенного всего».

Всепроникающие медиа, имея высочайший суггестивный эффект, воздействуют на когнитивную, аффективную и поведенческую сферу личности, сужая пространство «автономного действия».

Принуждение к потреблению информационного сигнала, медиастимула, каналы и источники которого находятся вне управления человеком, в формате шума и фона для другой деятельности отягощают среду развития личности, оказывает на неё мутагенный эффект. Влияние медиасферы вне пространственных и временных границ становится дискретным, а сознание человека, в особенности становящегося человека в условиях его морфологической незрелости, претерпевает лавину информационных и медийных стимулов, которые вынуждено обрабатывать или, «накапливая», переходить в иные состояния, пограничные здоровому. Вынужденность постоянной оценки сигнала погружает личность в условия противления обществу, ставит перед необходимостью усилий для сохранения самоидентичности в противовес демонстрируемых образцов поведения, часто противоречивого и девиантного (или пока её понимаемого как девиантного).

Адаптация личности к новой медиасреде в условиях медиалогики социальной жизни актуализирована осознанием необходимости сохранения личностного бытия. Автономия личности понимается и как условие, и как результат феномена личностной экзистенции в мире, в данном пространстве и времени. В дискурсе постмодерна «симулякрами» бытия «Другого», как и бытия «Мира», выступают новые практики коммуницирования и трансляции знания, исключающие социально-культурные и ценностно-мировоззренческие опоры. Потребность людей в настоящей реальности утрачивается в пользу «информационно-компьютерного бытия», которое важнее традиционного, «ибо основную часть времени они взаимодействуют с экранами, не нуждаясь в предметных прототипах ${ }^{4} »$.

\footnotetext{
${ }^{1}$ McLuhan M. Understanding Media: The Extensions of Man, 1964.

${ }^{2}$ Коломиец, В. П. Социология массовой коммуникации в обществе коммуникационного изобилия // Социологические исследования. - 2017. - № 6. - С. 3-14.

${ }^{3}$ Полянина А. К., Юрчук В. С. Произвол как субстанциональный источник автономии личности и её проявления в социально-правовом общении // История государства и права. - № 2. - 2017. - С. 6-9.

${ }^{4}$ Кутырев, В. А. Пост-пред-гипер-контр-модернизм: концы и начала // Вопросы философии. - 1998. № 5. - C. 138.
} 
Воплощение автономности как свободы от принуждающего действия медиа требует преодоления внешнего принуждающего контроля путём выхода из большинства культурных и социальных дискурсов, пресекая возможность медиа «записывать на человеке свои знаки и коды ${ }^{5}$ ». Однако дерзновение и смелость на начальном этапе требует отвержения нормативности медиапотребления, противопоставления сложившимся в обществе (релевантной группе) паттернам медиаповедения, чтобы в конце превратить человека в автономного социального субъекта.

Страх перед заражением и социальной близостью обусловил всплеск медиапотребления, наблюдаемый сегодня в мире всеми аналитиками, который выражен в росте интернет трафика (в среднем на 30\%), объема просмотра ТВ-контента, увеличении нагрузки на соцсети и мессенджеры (на 97\%). В 2020 г. мировое сообщество оказалось в ситуации мирового коллапса и информационного «шторма». Стратегия «локдауна» изменила паттерны медиапотребления и форматы управления источниками медиасигналов. Наши ранние исследования покали существование корреляции между степенью незащищённости жизненного пространства от медиасигналов, потребляемых в фоновом режиме (медиашумом), и уровнем стресса, в частности, состоянием повышенной тревожности. При этом локацией наиболее агрессивного медиашума по выявленной статистике значится место постоянного проживания: квартира, общежитие, дом. В ситуации проживания в вынужденной замкнутости медиашум (шум от медиасигнала в формате фона, например, постоянная работа ТВ-сигнала) формирует одну из самых сложных психоэмоциональных состояний, дом потерял статус комфортного места уединения.

Регулирование давления информационных и медийных систем, контроль над медиапотредлением, в том числе, ограничение для формирующихся личностей - детей доступности средств воспроизведения медиа, представляется ведущим фактором развития или депривации.

Одновременно с этим способность к адаптации к стрессогенному влиянию информационного пространства становится новым стратификационным признаком, заменяющим собою прежние. Поиск адаптивных стратегий и представление их детям для усвоения есть задача «ближнего круга» развития - семьи и школы, то есть классических акторов социализации.

Таким образом, продолжение тенденции уплотнения коммуникаций, концентрации медийной связанности современного общества всё настойчивее требует выработки адекватного механизма защиты от медиасигнала, часто неосознаваемого, потребляемого в формате фона. Реализация этой задачи стоит перед всем обществом, государством и семьёй, путём созданием единого представления о нормах медиапотребления и коммуницирования как в качественном, так в количественном аспекте.

В статье затрагивается проблема сохранения устойчивости структур личности в условиях нарастающего уплотнения медийных коммуникаций и экспансии медиалогики всего жизненного пространства. Отмечается роль когнитивного контроля над потоками информации и, прежде всего, медийной информации, в целях сохранения автономии личности и её неприкосновенности. Специфической формой насилия автор называет трансляцию медийных потоков, потребляемых субъектом без его согласия, чаще всего, в формате фона, например аудиосигнал в форме аудиорекламы. Фоновое потребление медиаинформации становится паттерном медиаповедения, деформирует личностные структуры и трансформирует всё современное общество.

The article deals with the problem of maintaining the stability of personality structures in the conditions of increasing compaction of media communications and the expansion of the medialogics of the entire living space. The role of cognitive control over the flow of information, and above all, media information, in order to preserve the autonomy of the individual and its integrity is noted. The author calls a specific form of violence the broadcast of media streams consumed by the subject without his consent, most often in the background format, for example, an audio signal in the form of an audio ad. Background consumption of media information becomes a pattern of media behavior, deforms personal structures and transforms the entire modern society.

\footnotetext{
${ }^{5}$ Историко-философское введение (от Конфуция до Бодрийяра): учеб. пособие / Под ред. Л. Я. Курочкиной. - Воронеж: ГОУВПО «Воронежский государственный технический университет», 2008. - 296 с.
} 